\title{
LITERARY TEXT AS A FACTOR IN THE FORMATION OF THE PROFESSIONAL PROGRAM OF A MILITARY SERVANT
}

\author{
Bybyk S. P.
}

\section{INTRODUCTION}

In the context of the development of such an important social field as professionalism, it is important to pay attention to the role of language and culture in the development of certain competencies of future professionals.

The anthropocentric approach of modern science requires taking into account the linguistic and aesthetic, linguistic and cultural components in the educational environment. It is a question of studying of art, journalistic, scientific texts which allow to form both the positive attitude to the chosen profession, and representation of a typical model of the professional, to receive aesthetic psychoemotional motivation for the future professional activity.

In the proposed study on the language of poetic and prose works about the war, emphasis is placed on the linguistic and aesthetic potential of works for the formation of consciousness of future soldiers, military servant. As the focus is on the courage and professionalism of the military man - defender of Ukraine.

It is the linguistic and aesthetic component, a positive (adequate) psychoemotional component that we consider necessary for the implementation of the numerous requirements set by the professional profile of a military servant. Cultural centrism as a basis of patriotism, devotion, resilience is designed for the socio-psychological characteristics of military servant who provide stability in this profession ${ }^{1}$.

\section{Professional discourse and principles of professiogram modeling}

The urgency of the problem of forming micro-societies, in particular professional ones, by type of activity, in modern everyday culture does not cause, in our opinion, any doubts. The development of private entrepreneurship and public initiatives stimulates further microstructuring of the community according to a wide range of interests. However, the

\footnotetext{
1 Про затвердження Методики розроблення професійних стандартів : Наказ Міністерства соціальної політики України від 22.01.2018 № 74 . URL: http://https://zakon.rada.gov.ua/laws/show/z0165-18
} 
traditional classification of social groups by professions is preserved, the generalized description of which is represented by the professiogram. The latter is based on the methodology of social psychology. Of course, the creation of a system of requirements for a person working in a particular profession can occur in two ways: theoretical and practical.

According to the general principles, professiograms can be complex, targeted, private, special ${ }^{2}$. Any professiogram involves several factors:

1. Physiological (physiological, medical and biological characteristics of the specialty).

2. Sanitary and hygienic (in terms of operating conditions or the impact of the activity on the human body).

3. Psychological (requirements for the human psyche: external picture of work, in particular the nature of the working day, its rhythm, job description; description of the internal picture of work, so the reactions of the individual, his integral abilities - orientation, character, abilities, temperament, experience; manifestations of mental reactions in the process of activity: will, attention, thinking and features of psychomotor skills).

4. Sociological.

5. Economic and organizational.

As a result of application of certain requirements the model of behavior of the individual in the corresponding microsociety is being formed.

From the culture-centric approach the professiogram should cover features of professional discourse with: communicative-pragmatic components; historiography of the profession represented by journalistic, scientific (including encyclopedic-reference) and artistic texts; history of scientific and educational centers for the training of relevant specialists.

Of course, each profession places different demands on the physical, psychophysiological and psychological properties of person, which manifest themselves in certain types of interactions: bionomic ("man - nature"); techno-economic ("man - technology"); socionomic ("man - man"); symptomatic ("man - sign system"); arthonomic ("man - an artistic image") ${ }^{3}$.Actually activity, psycho-emotional, social, communicative characteristics determine the features of a certain professional discourse. Under the latter we propose to understand the model of socio-linguistic interaction of people aimed at realizing the need for work, creating its

2 Военная профессиология: учебник ; под общей ред. А.Г. Караяни, Ю.Г. Сулимова. Москва : Военный университет, 2004. 276с.

${ }^{3}$ Климов Е.А. Психология профессионального самоопределения : учеб. пособие. Москва : Издательский центр «Академия», 2005. 304 с. 
products, informing about it, as well as receiving moral and material rewards for work.

Professional discourse requires specific conditions and means of organizing activities, from a communicative-pragmatic point of view lexical and grammatical techniques, genre and style resources of oral and written communication of a professional person. Thus, it is a synthetic model of human activity with complex architecture. ${ }^{4}$

The integral dominant of this structure is the linguistic personalityspecialist, to which the society forms the requirements:

- sufficient to meet the semi-official and official communication possession of the literary standard (supportive speech, persuasive, neutral, mentoring communicative competence);

- proper mastery of literary language to participate in the scientific and educational process of the relevant professionally oriented direction;

- ability to create texts of different genre and style with a special lexical and thematic content (mastery of terminology).

In addition, we draw attention to the fact that in the process of learning professional competencies for the formation of a professional profile, it is important to take into account the linguistic and aesthetic, linguistic and cultural components. It is a question of studying of art, journalistic, scientific texts which allow forming of both positive attitude to the chosen profession and representation of a typical model of the professional, to receive aesthetic psychoemotional motivation for the future professional activity.

The proposed research is aimed at understanding of modern poetic and prose works, which focus on the professionalism of the military man - the defender of Ukraine.

Thus, we propose to add aesthetic, culture-centric factors to the factors of professional profile modeling, which are projected on socio-psychological ones, which ensure activity stability in one or another profession.

\section{Artistic text as a linguistic and aesthetic source of formation of professional qualities of a military servant}

Artistic text is an important component of language and aesthetic education. For the formation of socio-psychological competencies an important role is played by reading and linguistic-stylistic analysis of prose and poetic works about war, soldiers.

4 Колеснікова I. Професійний дискурс: класифікаційна матриця. URL: http://dspace.tnpu.edu.ua/bitstream/123456789/7708/1/Kolesnikova.pdf (останнє звернення: 16.02.2021). 
The work of Borys Humeniuk, a poet-warrior, is relevant in modern Ukrainian literature. His works represent an individual-authorial assessment of the philosophy of war and man from the war, at war, after the war. They have a clear journalistic component, because the texts deal with important social issues. Realistic is interspersed with bizarre, mythical, surreal, because a person in war suffers from socio-psychological trauma and physical trauma. Attention to such works is also relevant because: "We define psychological strategies for studying the traumatic experience of society as a collective phenomenon of experiencing events that are interpreted as traumatic; these are partially unconscious, simplified models of behavior that can be analyzed by the manifestations of cognitive, conative and behavioral components. We believe that such approach will "capture" the cumulative effect of society on the individual, to understand the conscious or unconscious desire of the subject to meet the standards of response / behavior of the reference group, to diversify the channels of social relations, etc. " ${ }^{\circ}$.

It is the methods of linguistic-stylistic analysis that make it possible to trace on the example of an artistic text as a reflection of a combatant the interaction of three psychological vectors - subjectivity, reflectivity and trauma - which determine the perception of military conflict and verbalization of its linguocognitive models.

First of all, such a nuclear component of B. Humeniuk's works about the war - WAR - attracts attention. The subject perception of the poet of armed struggle are conveyed by the epithets "personal war", "own war". The lyrical hero sees war as arithmetic: he keeps records of deaths, ammunition, bullets - people and metal, erasing from existence the years of peaceful life:

Дивне ие відчуття коли відкриваєш рахунок / Другого дня другого місяия своєї персональної війни / Відкриваєш рахунок своїм убитим / На июю пору у тебе назбиралося / чимало непогашених рахунків. / Кожного року ти сплачуєш по одному року власному життю ${ }^{6}$.

B. Humeniuk's texts help to express in the professional profile of the future military servant such features of the soldier as rigidity, tension, confidence:

Тому що у нього були руки чоловіка-воӥна / Бога війни; Щоб уже наступної миті перетворитися / на суворих чоловіків; У такі хвилини я почуваюся / Хоробрим центуріоном / Непереможним гладіатором / Історія людства / За останні декілька тисяч років / Воскресає в мені / Повстає із попелу; $\mathbf{T u}$ - звір / Щоб ти там про себе не думав / Ти лиш

${ }^{5}$ Мяленко В.В. Психологічні особливості опрацювання травматичного досвіду спільнотою воїнів, які набули бойовий досвід в АТО/ООС. Проблеми політичної психологіï. Збірник наукових праџь. 2019. Випуск 8 (22). С. 124.

${ }^{6}$ The spelling of the original is preserved in the quotations 
звір / Звір цивілізований сучасний світанковий / Хижак який полює вдень і має сховок-житло на ніч. / Ти - звір щңо навчився споживати м'ясо / приперчене й присолене.

The main association with war is death and ruin.

The militarized picture of the world determines the actualization of the concept of DEATH and the corresponding epithets:Ці чайки над полем бою - вони такі недоречні / Я ще можу зрозуміти круків /Вони здавна живляться плоттю загиблих воӥнів. The epic book "Dead Warrior" is emphatically emotionless, petrified as a memorial on the grave.

Linguistic and aesthetic components of the image of the RUIN are metaphors in which one of the components is a military token. The latter significantly affects the nature of the metaphor of time. It makes it surreal:Сонце має догоріти наче палаюча шина; Літо шкварчить / як начинений шрапнеллю голубець; літо покірно лежить біля наших ніг / наче переляканий вибухами собака; Місяць у нього це горло крупнокаліберної гармати; А море - це розплавлене олово.

The tokens war and SOLDIER are thematically related. In B. Humeniuk's poetic texts war is a cradle of a warrior that shows metaphorical structures:Чи знаєте ви як народжуються солдати? / Ви не знаєте як народжуються солдати / Солдати народжуються з війни / Солдати народжуються з болю / Любов може обернути чоловіка на солдата / Солдатом можна стати з ненависті - / Довелося й таких бачити - / Але найчастіше солдати народжуються / 3 війни.

In the Ukrainian literary language there are two synonymous series for naming military servant:

a) СОЛДАТ (soldier of the lowest rank of the ground forces), РЯДОВЙЙ, БОє́ЦЬ, СТРІЛЕ́ЦЬ, СЛУЖЙВИЙ, МОСКӒЛЬ, СЛУ́ЖБА, РЯДОВЙК, ЖОВНІР;

б) ВОЯ̆К (military servant or participant in battles, wars), БОЕ́ЦЬ, ВӦЇН, ВОЯ́КА, ВОЯЧЙСЬКО, ВОЯЧНЯ́, ЗВИТЯ́ЖЕЦЬ, ВИ́ТЯЗЬ, ВОЙОВНЙК, ЗБОРО́НЕЦЬ, РА́ТНИК, РАТОБО́РЕЦЬ, РУБА́КА (one who is proficient in cold steel); БОЙОВЙК (member of any combat group, detachment) ${ }^{7}$.

The Russian-Ukrainian war of 2014 again actualized the commonly used "volunteer" for the name of a soldier, the intimate "brother", and also made the name of the maidanivets' (=Maidan soldier) a word of modern times: Te що можуть собі дозволити поети /Добровольцю не до лиця; I каже: хлопиі я усе розумію ви мене ненавидите / $i$ є за шо / Не женіть мене хочу бути вам братом / Хочу кров'ю змити свою ганьбу / Коли їхній

${ }^{7}$ Бурячок А.А. та ін. Словник синонімів української мови : В двох томах. Т. 1. Київ : Наукова думка, 2001. С. 458, 58. 
підрозділ потрапив у засідку / Закінчилися набої і усі довкола вже були мертві / Залишився лише він і майданівець Павло / Вони подивилися один одному в очі обнялися / Пробач мені брате.

B. Humeniuk's poetic texts on the theme of war actualize the names of military professions - proofreader, machine guпnеr: Вистежуємо ворожих кориктувальників вогню; В ию мить у місячному світлі цей солдат / більше нагадував астронома / Аніж кулеметника піхотного батальйону / Який в телескоп розглядає зоряне небо / Сподіваючись вловити порух далеких незнаних світів.

B. Humeniuk's lyric-epic short stories and a number of conventional figurative symbols of the military - "Climber", "Adelweiss", "Clerc" and others:Гранатометник з позивним "Зяблик", який за мить до того голосно присьорбував з кружки щойно запарений чай, принишк у своєму кутку, прислухався до розмови («Аспірант»); «Лемку, розкажіть ще про Бога», - просив старшого побратима задерикуватий гранатометник з позивним Черемош, підхоплюючи нитку якоїсь давнішої бесіди, що за півроку спільної служби вони наплели тут удвох, акурат на гуиульський килимок до господи («Лемко і Черемош»). Conditional names of fighters are next to the functionally loaded ironically colored ones: Бувалі бійці по-приколу різні позивні їм придумали. Том $\boldsymbol{i}$ Джері, Штангель і Циркуль, Хижак $і$ Чужий. Генерали піщаних кар'єрів. Чому пішаних? Піски ж бо. А в Пісках у нас всі генерали. Щоб боялися. I трималися подалі відсіль («Третя ротація»).

In B. Humeniuk's poetry it is not possible to notice such a feature - the activity of pronoun adjectives-epithets. Their actualization is connected with the subjectivization of lyrical narratives, the union of the lyrical "I", "we" and "I" of the poet-warrior. Stylistically accentuated possessive epithets:

свій'your' (Той хто повторює тезу про слово / Ще й переконує мене взяти його гаслом на свій щцт;Одягаю своюпершу кевларову каску; Приміряю свій перший бронежилет; Не дбає про риму / Коли пише смс-повідомлення свойй дівчині;Навіть якщо ти не бачив обличчя свого ворога);

наш'our' (Наш чотовий - чоловік з химерами / Коли над полем бою сходить сонце / Він каже що ие на дальньому блокпосту запалили шину...; Чому воно солоне? Тому що у ньому наші сльози nim сеча $\boldsymbol{i}$ кров - Воно протікає крізь нас; Але сталася біда - прийшла вата у нашу хату;Двісті метрів від наших окопів до ӥхніх окопів);

твій'уоur' (Твою крайну громадяни обміняють / на дрібну готівку харч; Він[слід'trace']нагадує твій народ / Теж такий безпомічний та зворушливо-безглуздий / Зі своӥми смішними колючками / Теж такий полохливий $i$ замріяний / Котрому не знайшлося місия у цьому доброму світі / Твій народ розгублений $i$ безпорадний / Наче викинуте в чернігівські світи кактусеня / Із далекого Техасу). 
At the center of the material world of war are WEAPONS and ammunition, relevant lexical and thematic groups of words:Послабляю ремінець каски;Арсенал украӥнського поета новітніх часів - / Бінокля запасний магазин чотири гранати; Його одинока тінь бере тепловізор / Опирається ліктями і грудьми на земляний бруствер / Ретельно оглядає периметр; РПГ кулемет автомати СВД каски бронежилети / Лежали акуратно складені в траві під деревом; Бронежилети не воюють / Ще нікому не приніс перемогу щит / Тільки ніж / Тож віднедавна я вчуся думати про свій ніж / бути як ніж / Бути як зброя («Ікона»).

The professionalism, jargonisms in the language of the military servants is difficult to record when you need to organize special records. But the artistic text gives such rare fixations. Therefore, it is valuable for a fuller picture of the language component of the professional profile of a military servant: Треба готуватися відбивати атаку. Наводити арту(«Лемко i Черемош»); 3 десятої години б'ють міномети, .. а з дванадиятої кулемет прачює, кошмарить снайпер («Опришки»); Пацани на посту давай поливати його з калашів, а тут дерева, мандраж, відстань; Засікли його в тепловізор, вальнули, а він, гад, поміняв позицію, $i$ знову бах-бах $і$ бах-бах («Перша ротація»); По Пісках команда: «Нори!». В укриття, тобто. Починається масовий арт-обстріл наших позииій ворогом. Спостерігач чує далеку канонаду чи бачить спалахи на горизонті, «ви́ходи», кажуть на фронті, $i$ сповімає по рації усі підрозділи; Інший, імовірно, й досі на нейтралці лежить («Третя ротація»); Перепочинь хвильку / Встигнеш іще зі свого калаша потатакати; А зараз як? / А зараз у мене немає ворога / Тобто ворог доволі умовний / У мене є сектор обстрілу / Он та зельонка; Ця ікона на свіжому згарищі, у розбомбленій «градами» хаті, виглядала геть беззахисно і якось навіть недоречно («Ікона»).

One of the ways to paraphrase the war is a secondary nominationuniverb, for example, one that emphasizes the breadth of hostilities: Biн лише шукає приводу, щоб підняти проти нас авіацію $i$ почати повномасштабку («Четверта ротація»).

In the poetic consciousness, weapons are subjectivized, because the lyrical "I" appears through personal verb forms. In particular, the verbs of the 2nd person singular, used in the meaning of the $1 \mathrm{st}$ :

Коли чистишзброю / Коли щзодня чистищ зброю / Розтираєш ї̈ духмяними оліями / Затуляєш ї̈ собою а сам мокнеш на дощчі / Пеленасш ї̈ як малу дитину.

The ніж ("Knife") is also an intimate name for a weapon. The use of this noun is accompanied by emotional and evaluative adjectives дорогий('dear'), свій ('own'): Як я люблю свою зброю! Особливо ніж⿻! Ось цей - ручка ізолентою обмотана, - дорогий, свій. Що таке 
ніж? Як я раніше до нього ставився? Олівия затесати, порізати хліб. A тепер? Ні! Коли прийде мій час $i$ їхній снайпер першим мене побачить, я хочу, щоб мені його в домовину поклали. Нехай на тому світі буде при мені. Звісно, якщо ие буде не фугас чи пряме попадання з крупного калібру, $i$ буде що збирати, а не як у друга Тура, від якого знайшли лише одну ногу з усього тіла; впізнавали по черевику; словом, якщо буде домовина, могила, тіло і, відповідно, куди й кому класти

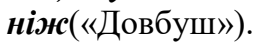

The танк ('tank') in the writer's imagination is a bizarre creature. This is expressed by psychologized epithets, comparisons, verbal metaphors: $M u$ бачимо ще з десяток ворожих танків, які без поспіху пересуваються по полю, наче химерні чудовиська з рільмів жахів. Гусеницями вишукують наших («Марево»).

Metal weapons in B. Humeniuk's poetry are personified:

a) it is animated by comparison with animals, birds: $A$ кулі літають 3 такою смертельною швидкістю / Наче випущені з арбалета залізні птахи; Кулі прилетіли з по той бік війни / Наче злі шершні; Чотири ручних гранати які крадькома / визирали з підсумка / Гранатометника Макса з Луганська / Коли почули таке поховалися в підсумок / наче злякані кошенята.

b) it is anthropomorphized: Куля сама собі знайде иіль переконують / досвідчені стрільиі / Котра розумна;Автомат ревнує юнака до дівчини / Хлопець ще не навчився розуміти складну мову / Мовчазних автоматів / Однак загадкова мова кохання / йому теж незнайома:Дурна міна чи тупий снаряд.

Military rhetoric seeps into every verlibrove stanza of B. Humeniuk. From this point of view, epithets are indicative of adjectives, in which the definition indicates damage, disorder, incompleteness of realities: Jimo прийшло / щоб залишити на шкірі опіки / від стріляних гільз / і піти на протезах / замість відірваних ніг; На подвір'ї початкової школи розкидані іграшки / Недобудовані піщані замки мости залізниці / Розтоптані дорослим чоботом / Вивернуті ранці / Покидані недочитані прибиті курявою книжки; Покинуті тварини Покинуті будинки Покинуті могили / Пробита стеля обірвана люстра вирвані розетки / Бите скло обсипана штукатурка виламані двері; Лише пісок від розтрощених бетонних плит; Де прострелені голови розпороті животи / теплі нутрощі на твойх руках / Коли ти марно намагаєшся затулити / в животі побратима отакенну рану?

In B. Humeniuk's short stories a concrete-sensual image of real sound sensations of war and battle is created. The poet did not ignore the display of psycho-emotional perception of these sounds, to which it is difficult to get used:Розриви снарядів, свист куль, гул двигунів, хлопки мін, крики живих, стогін поранених, голоси «речників», які транслюють інформ- 
повідомлення з фронтів, гидке деренчання рикометів. Звуки застерігають, інформують, передують страху, небезпеиі, а іноді смерті («Сон»).

Bullets, grenades, ammunition are anthropomorphized, endowed with mythical dynamic properties. Compare the corresponding verb metaphors: Ти коли-небудь звертав увагу яке коротке життя / в кулі? - / Наче читає мої думки - / Не влучила - марно прожила жстття Даремно / приходила у світ; В ящику важко мовчать протитанкові гранати; Птахи пасуться в небі / Птахи полюють на здобич / Кулі полюють на птахів / Куля поцілила в птах.

Sound images of war are especially intimate when they are reinforced by national and cultural stereotypes: Якщฺо раніше ви не чули як передзенькуються набої / Вам можездатися що то різдвяні дзвіночки: / До вас із радісною новиною прийшли колядники.

The bullet, projectile from the enemy, combat shots acquire several paraphrases, which are born by the conversational practice of the military, compare in this function of the nomination подарунок('gift'), сюрприз ('surprise'), перекладач ('translator'): Подарунок від непроханих гостей / Треба буде подякувати на таке Сюрприз назад відіслати; Одразу почитаєш татакати. /Ти можеш сам без перекладача порозмовляти $/ У$ мене теж такий перекладач знайдеться.

The humanism of the linguosophy of murder on war covers the linguistic and psychological separation of the cannon casing as a subject part of the shooting: it is emotionally difficult, traumatic for the psyche to count the bodies of the killed, and cold metal cannon seems easier. This is how the lyrical hero protects his feelings, by distancing himself from the reality of death and fratricide. In this case, the synecdoche acts as a protrusion of the cannon, it is assigned the function of a scale:Я неміряювійнуубитими-ие не личить солдату - кількістю тобою знятих, пійманих на приціл. Але ще ганебніше рахувати ордени на грудях чи на погонах зірки. Я рахую гільзи. От і все. Коли стріляних гільз набирається повний підсумок, я йду подалі у ліс. Там, щзоб ніхто не бачив, акуратно закопую їх. Кожну гільзу я кладу акуратно в землю, як нас Бог кладе. Відчуваю, що так правильно. Три підсумки за два роки, три братські могили, відомі лише мені («Довбуш»).

Accentuated in the linguosophy of military existence, the militarism of the куля('bullet') is involved in the language game. In the context of the ambiguity of the word «важити» ('weigh'). The verb to weigh in textual use realizes the first two meanings -1 . Have a certain weight. 2 . Have value; mean. The writer as a philosopher correlates the weight of the ball and the soul, compare in "Novels": Пам'ятаю лише, що влучив. Час нічого не важить. Особливо для нього. У кого влучив. А якщо й важить, то набагато. Щось із дев'ять грамів. Вага кулі. I душі. Господній 
мікрочіп. As a result, a new sacralized periphrasis is born куля $=$ мікрочіп господній ('bullet = microchip of God').

The main function of the weapon - to shoot, the purpose - to kill the enemy. Therefore, metaphors вбити сніговика(to kill a snowman),стрельнути зірку(to shoot a star) are painfully vulnerable, behind which there is a second semantic plan - to kill life, to kill the future, to kill the planet. Compare bizarre macro images:Сніговика теж можуть вбити / Автоматною чергою чи пострілом з граду / $A$ сніг збезчестити $і$ затоптати / замість очей встромимо патрони калібру 5.45 / Замість носа - снаряд АГееСа / Вкладемо до рук автомата / Сніговики теж мусять захищатися / I поросимо повоювати за нас;Сьогодні стрельнув зірку / Зійшла над кущем навпроти нашого окопу / O пів на четверту ранку / Вигулькнула нізвідки / Схожа на відблиск оптики ворожсого снайпера / Чи спалах цигарки в зубах у дурнуватого сепара / Я відкрив вогонь.

Contradictory specific-sensory associations are caused by the verbal metaphor of strafing: Твій будинок накриє крупним калібром / 3 піонів чи гвоздик.In fact, this is not about flowers. We are talking about a special weapon - a self-propelled artillery gun, which in the name has a conditional component "Peony", "Carnation". These weapons of mass destruction were deconserved during the Russian-Ukrainian war (January 2015).The author of "Poems ..." by the common name "peony", "carnation", on the one hand, tries to soften military rhetoric. On the other hand, he actualizes the associativesemantic connection with the form, color of flowers, to which the rupture of the projectile is likened. The house, covered with projectiles of flowers, has a second associative plan: it looks like a grave with flowers laid on it.

The structure of a number of metaphors includes nouns and adjectives as carriers of military semantics. Example: Волонтерські пряники $\boldsymbol{i}$ шоколад / Армійський сухпай; Цей світ йому не належить. Він окупований («Заради цього»), Сонце має догоріти наче палаюча шина; Літо шкварчить / як начинений шрапнеллю голубець; Місяць у нього це горло крупнокаліберної гармати; А море - це розплавлене олово; У нас тут літо Кіндрате. / Літо - як постріл з САУ / Літо як пряме попадання в хату / в хату де ховалася від обстрілу та сім'я; Сонце як випалений вибухом окоп / Сонце як розплавлена броня; сонце висить над головою / як ворожий безпілотник.

B. Humeniuk creates such psychologically complex images that combine metaphors, comparisons and paraphrases: $А$ на зміну дню небо викотить на позицію / Крупнокаліберну гармату місяця / I попелом осиплеться ніч; Сонце розгорталося над Донецьком, наче підпалений диверсійною групою військовий склад, наче вхід у потойбіччя, який, мовби печера в пригодницьких сагах, відкривається враз, наче намальована мішень, наче тунель, з якого от-от виїде на нас пекельний поӥзд («Аспірант», 
"Postgraduate"). The world appears in the imagination of a poet who went through the war, through the prism of battle paintings.

Reading works about the war creates the preconditions for a generalized artistic perception of military realities. And this in its turn strengthens the social role of art, which can not be rejected in the process of forming professiograms, in particular the military servants.

\section{CONCLUSIONS}

Thus, the poetic and prose language of $\mathrm{B}$. Humeniuk broadcasts the theme of war. This leads to the distinction of end-to-end associative-image lines - WAR, MAN ("warrior", "enemy"), LIFE, DEATH, WEAPONS. Psychologized, intimate epithets, metaphors help to create an emotional background.

Analysis of the specific sensuality of the created linguistic and aesthetic images contributes to the formation of social and psychological competencies in military servant. Elements of professional discourse (military vocabulary, professionalism, military jargon) contribute to the strengthening of subjectivity in the perception of artistic creativity, they transmit professional experience from generation to generation.

Thus, for educational purposes, artistic texts can also be used in the formation of the professional profile of a military servant. In this way, one of the important components of the culture-centric language and aesthetic education of the younger generation of defenders of the homeland is realized.

\section{SUMMARY}

The study emphasizes the role of language and aesthetic education in the formation of the professional profile of a military sevant. The issue of attention to literary texts is revealed in the context of the development of such an important social field as professionalism. It is noted that the anthropocentric approach of modern science requires taking into account the linguistic-aesthetic, linguo-cultural components in the educational environment. It is an issue of studying of art, journalistic, scientific texts which allow to form both the positive attitude to the chosen profession, and representation of a typical model of the professional, to receive aesthetic psychoemotional motivation for the future professional activity.

In the proposed study on the basis of the language of poetic and prose works of Borys Humeniuk about the war, the emphasis is on the linguistic and aesthetic potential of the works for the formation of the consciousness of future soldiers, military servants. Because the focus is on the courage and professionalism of the military defender of Ukraine.

Emphasis is placed on cultural centrism as the basis of patriotism, devotion, and socio-psychological stability, which ensure activity stability in the military profession. 


\section{REFERENCES}

1. Бурячок А.А. та ін. Словник синонімів української мови : В двох томах. Т. 1. Київ : Наукова думка, 2001. 1040 с.

2. Гуменюк Б. Вірші з війни. Київ, 2018.

3. Мяленко В.В. Психологічні особливості опрацювання травматичного досвіду спільнотою воїнів, які набули бойовий досвід в АТО/ООС. Проблеми політичної психології. Збірник наукових праџь. 2019. Випуск 8 (22). С. 115-126.

4. Военная профессиология: учебник ; под общей ред. А.Г. Караяни, Ю.Г. Сулимова. Москва : Военный университет, 2004. 276 с.

5. Климов Е.А. Психология профессионального самоопределения : учеб. пособие. Москва : Издательский центр «Академия», 2005. 304 с.

6. Колеснікова I. Професійний дискурс: класифікаційна матриця. URL: http://dspace.tnpu.edu.ua/bitstream/123456789/7708/1/ Kolesnikova.pdf (останне звернення: 16.02.2021).

7. Словник української мови : В 11-ти т. Київ : Наукова думка, 1970-1980.

8. Про затвердження Методики розроблення професійних стандартів : Наказ Міністерства соціальної політики України від 22.01.2018 № 74. URL: http://https://zakon.rada.gov.ua/laws/show/z0165-18.

Information about the author: Bybyk S. P., Doctor of Philological Sciences, Professor Institute of the Ukrainian Language of the National Academy of Sciences of Ukraine 4, Hrushevskoho str., Kyiv, 01001, Ukraine 